\title{
Intergeneric Hybridizaton between Schlumbergera Lem. and Hatiora Britt. \& Rose (Cactaceae)
}

\author{
Thomas H. Boyle1 \\ Department of Plant and Soil Sciences, French Hall, University of Massachusetts, Amherst, MA 01003 \\ Alexander Idnurm \\ School of Botany, The University of Melbourne, Parkville, Victoria 3010, Australia

\begin{abstract}
ADDITIONAL INDEX WORDS. Easter cactus, growth regulators, holiday cactus, Hatiora gaertneri, Hatiora $\times$ graeseri, Hatiora rosea, isozymes, Schlumbergera truncata, Schlumbergera $\times$ buckleyi, seed set
\end{abstract}

\begin{abstract}
Post-pollination barriers to intergeneric hybridization between Easter cactus [Hatiora gaertneri (Regel) Barthlott, H. rosea (Lagerheim) Barthlott, and H. xgraeseri Barthlott ex D. Hunt] and holiday cactus [Schlumbergera truncata (Haworth) Moran and $S$. $\times$ buckleyi (Buckley) Tjaden] were determined and procedures were devised for circumventing these barriers. Examination of Hatiora and Schlumbergera pistils at 72 hours after intergeneric crosses indicated no abnormalities in pollen germination or pollen tube growth in the upper style. Pollen tubes of Hatiora were arrested in the lower half of Schlumbergera styles and failed to enter the ovary. Schlumbergera pollen tubes exhibited normal growth in Hatiora styles but most tubes lost directionality, burst, or failed to penetrate the micropyles after reaching the ovary. Three growth regulators (BA, GA 3 and NAAm) were applied individually to ovaries of 'Crimson Giant' Easter cactus after intergeneric crosses. $\mathrm{GA}_{3}$ and NAAm increased fruit set compared to the control (lanolin alone) or BA but none of the fruit harvested 160 days after pollination contained mature embryos. Four progeny were obtained when a short-styled $\mathrm{S}$. $\times$ buckleyi clone was crossed as a female parent with $\mathrm{H}$. $\times$ graeseri. Isozyme patterns and morphological characteristics confirmed that the four progeny were intergeneric hybrids. This is the first report of successful intergeneric hybridization between Hatiora and Schlumbergera. Chemical names used: $N$-(phenylmethyl)-1H-purine-6-amine [benzyladenine (BA)]; gibberellic acid $\left(\mathbf{G A}_{3}\right) ; \alpha$-naphthaleneacetamide (NAAm).
\end{abstract}

Distant hybridization is commonly employed in breeding ornamental crops to produce novel and oftentimes unpredictable characters and to introgress desirable genes from wild to cultivated taxa (Langton, 1987). Usually, distant hybridization involves crossing different species within the same genus, but sometimes crosses are attempted between different genera. Barriers to distant hybridization can be prezygotic, postzygotic, or both, and are likely to be more severe in crosses between more distantly related taxa than those that are closely related (Ladizinsky, 1992).

Holiday cactus [Schlumbergera truncata and S. xbuckleyi (= interspecific hybrid of $S$. truncata and S. russelliana (Hooker) Britton \& Rose] and Easter cactus [Hatiora gaertneri, H. rosea, and their hybrid $(=H$. $\times$ graeseri $)]$ are grown as flowering potted plants (Boyle, 1997). Hatiora Britton \& Rose and Schlumbergera Lemaire, along with Lepismium Pfeiffer and Rhipsalis Gaertner, comprise the tribe Rhipsalideae which is one of nine tribes in the subfamily Cactoideae of the Cactaceae (Anderson, 2001; Barthlott, 1987; Barthlott and Taylor, 1995).

Numerous interspecific and intergeneric hybrids have been documented for the Cactaceae, some of which originated in the wild while others arose from deliberate crosses (Hawkes, 1982, 1983; Rowley, 1994). Interspecific hybrids have been produced by crossing H. gaertneri with H. rosea (Moran, 1953) and S. truncata with S. opuntioides (Löfgren \& Dusén) D. Hunt, S. orssichiana Barthlott \& McMillan, and S. russelliana (Barthlott and Rauh, 1977; McMillan and Horobin, 1995). To our knowledge, no intergeneric hybrids have been obtained from crossing Hatiora with Schlumbergera (Barthlott, 1987; McMillan and Horobin, 1995; Schumann, 1902).

Received for publication 28 Jan. 2003. Accepted for publication 21 Apr. 2003. Publication 3327 of the Massachusetts Agricultural Experiment Station. This material is based on work supported in part by the Cooperative State Research, Extension, Education Service, U.S. Department of Agriculture, Massachusetts Agricultural Experiment Station, under Project 746.

'To whom reprint requests should be addressed; e-mail tboyle@pssci.umass.edu.
Hybrids between Hatiora and Schlumbergera may serve as a bridge for introgressing desirable traits from one genus to the other. For instance, it may be possible to decrease flower bud abortion and increase flower longevity in holiday cactus by introgressing genes from Easter cactus, or to expand the flower color range and eliminate the cold period requirement for flowering in Easter cactus by transferring genes from holiday cactus. This study was performed to elucidate the postpollination barriers involved in crossing Easter cactus and holiday cactus, and to devise procedures to circumvent these barriers and produce viable intergeneric hybrids.

\section{Materials and Methods}

Plant material. Nine Hatora clones and six Schlumbergera clones were used for this study (Table 1). All clones were diploid $(2 n=22)$, male- and female-fertile, and highly self-incompatible (Boyle et al., 1994; Boyle, 1996; Parks, 2003). Parentage of the clones was unknown except for those developed at the University of Massachusetts (Table 1). Henceforth, all crosses will be presented as pistillate parent $\mathrm{x}$ pollen parent.

GENERAL PROCEDURES. Experiments were conducted in a glasshouse or growth chamber (model I-35LVL; Percival Scientific, Boone, Iowa). Glasshouse conditions were $18 \pm 2{ }^{\circ} \mathrm{C}$ nights $/ 20 \pm 2$ ${ }^{\circ} \mathrm{C}$ days, $\leq 600 \mu \mathrm{mol} \cdot \mathrm{s}^{-1} \cdot \mathrm{m}^{-2}$ photosynthetic photon flux $(P P F)$, and natural daylengths. Growth chamber conditions were $20 \pm 1^{\circ} \mathrm{C}, 75$ $\pm 5 \%$ relative humidity $(\mathrm{RH})$, and $50 \pm 8 \mu \mathrm{mol} \cdot \mathrm{s}^{-1} \cdot \mathrm{m}^{-2} P P F$ for 12 $\mathrm{h}$ daily from cool-white fluorescent lamps. Air temperatures and $P P F$ were monitored with a datalogger (model LI-1000; LI-COR, Lincoln, Nebr.) using an aspirated thermistor (model LI-1000-16) and quantum sensor (model LI-190SA). A HMI38 data processor equipped with a HMP35E probe (Vaisala Inc., Woburn, Mass.) was used for measuring RH. Plants were propagated and grown as described previously (Karle and Boyle, 1999).

Flowering of Hatiora and Schlumbergera was synchronized by 
Table 1. Easter cactus (EC) and holiday cactus (HC) clones used for study, their parentage, and source.

\begin{tabular}{|c|c|c|c|}
\hline Group & Clone & Parentage (female $\mathbf{x}$ male) & Source $^{2}$ \\
\hline \multirow[t]{5}{*}{$\overline{\mathrm{EC}}$} & AG942 & H. rosea & $\mathrm{AG}$ \\
\hline & Crimson Giant & H. gaertneri & MD \\
\hline & R931-8 & Andre $x$ Red Pride & MA \\
\hline & R9312-5 & Crimson Giant $x$ H. rosea $\left(\mathrm{BC}_{1}\right)$ & MA \\
\hline & R9343-3 & Crimson Giant $x$ H. rosea $\left(\mathrm{BC}_{1}\right)$ & MA \\
\hline \multirow[t]{5}{*}{$\mathrm{HC}$} & Abendroth 6 & Unknown & DK \\
\hline & Dark Marie & Unknown & GP \\
\hline & Rocket & Unknown & RG \\
\hline & S88-9 & Rocket $x$ Christmas Cactus $\left(\mathrm{F}_{1}\right)$ & MA \\
\hline & S90-38 & Christmas Cactus $\mathrm{x}$ Rocket $\left(\mathrm{F}_{1}\right)$ & MA \\
\hline
\end{tabular}

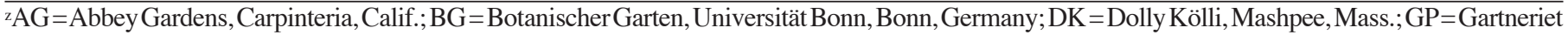
PKM, Odense, Denmark; MA = Univ. of Massachusetts, Amherst; MD = Univ. of Maryland, College Park; RG = Rainbow Gardens, Vista, Calif.

controlling temperature and photoperiod (Boyle, 1997). Flowers were emasculated $\approx 1 \mathrm{~d}$ before anthesis by removing the corolla and anthers with forceps and washing of the stigmatic lobes with deionized water to extricate adhering tissue. Pollination was performed $\approx 24 \mathrm{~h}$ after emasculation by rubbing recently-dehisced anthers on the stigmatic lobes. Each flower was pollinated once using fresh pollen collected from two or more flowers.

Seeds were cleaned by vacuum extraction (Boyle, 1994) and sown in 10-cm covered glass petri dishes containing one layer of blue blotter paper (Anchor Paper Co., Charlotte, N.C.) moistened with deionized water. Dishes were sealed with parafilm and placed in an incubator with $12 \mathrm{~h}$ days/ $12 \mathrm{~h}$ nights of $25 \pm 1 / 22 \pm 1{ }^{\circ} \mathrm{C}$ and a $12-\mathrm{h}$ photoperiod of $55 \pm 8 \mu \mathrm{mol} \cdot \mathrm{s}^{-1} \cdot \mathrm{m}^{-2}$ provided by cool-white fluorescent lamps. Asolution of $3 \alpha, 4,7,7 \alpha$-tetrahydro-2-[(trichloromethyl)thio]$1 H$-isoindole-1,3(2H)-dione (captan; $0.24 \mathrm{~g} / 100 \mathrm{mLdeionized} \mathrm{water)}$ was applied to blotter paper $1 \mathrm{~d}$ after sowing to protect seeds against pathogenic organisms. Numbers of germinated seeds (radicle $\geq 1$ $\mathrm{mm}$ ) were counted $30 \mathrm{~d}$ after sowing.

FruIT AND SEED SET FOLLOWING INTRA- AND INTERGENERIC Crosses. Five Easter cactus clones (AG942, Bonn 06524, 'Crimson Giant' R962-45, and R963-7) and five holiday cactus clones ('Abendroth 6', 'Dark Marie', 'Rocket', S90-38, and S9219-2) were used as female parents in intra- and intergeneric crosses. Each flower was pollinated once using pollen from two or more clones of $H . \times$ graeseri or $S$. truncata/S. ×buckleyi. Clones used as pollen donors in intrageneric crosses were cross-compatible with those used as female parents. Eight flowers or more were pollinated for each cross.

Lengths of the stigma lobes and styles (= distance from the base of the stigmatic lobes to the entrance of the ovary cavity) were determined for 10 flowers per female parent. Fruit were harvested from the Easter cactus and holiday cactus clones at $\approx 120$ and $\approx 180$ $\mathrm{d}$ after pollination (DAP), respectively. Seeds were cleaned and germinated as described previously and the numbers of germinated seeds were counted for each fruit. Percent fruit set and number of viable seeds per pollinated flower were calculated for each cross.

POLlen GERMinATION AND POLLEN TUBE GROWTH FOLLOWING INTRA- AND INTERGENERIC CROSSES. Plants of 'Crimson Giant' Easter cactus with several mature flower buds were transferred to a growth chamber. Flowers were pollinated using pollen from five $H$. $\times$ graeseri clones or ten $S$. truncata/S. $\times$ buckleyi clones. Composite pollen samples were prepared as described in Boyle (2001).
Pistils were harvested $72 \mathrm{~h}$ after pollination. To permit observation of pollen tubes in the ovary, the ovary wall was removed on two sides to yield a median longitudinal section $(\approx 2 \mathrm{~mm}$ thick) plus the attached style and stigma. Sectioned pistils were fixed in 3 ethanol : 1 glacial acetic acid (v/v) for $\geq 24 \mathrm{~h}$, softened in $10 \%(\mathrm{w} / \mathrm{v}) \mathrm{Na}_{2} \mathrm{SO}_{3}$ at $100{ }^{\circ} \mathrm{C}$ for $1 \mathrm{~h}$, stained overnight with $0.1 \%$ (w/v) decolorized aniline blue in $0.1 \mathrm{M} \mathrm{K}_{3} \mathrm{PO}_{4}$ (Martin, 1959), and examined with a epifluorescence microscope (Carl Zeiss, Inc., Thornwood, N.Y.) equipped with a 100-W high-pressure Hg lamp and a filter set for ultraviolet-violet waveband excitation (exciter filter BP 395-425, dichromatic beam splitter FT 425, and barrier filter LP 450).

Plants of two holiday cactus clones ('Rocket' and S9219-2) with mature flower buds were transferred to a growth chamber. Flowers were pollinated with pollen from eight $S$. truncata/S. $\times$ buckleyi clones or eight $H$. $\times$ graeseri clones. Pistils were harvested $72 \mathrm{~h}$ after pollination and sectioned, fixed, softened, stained, and examined as described above.

For each cross, data were collected on pollen adhesion and germination on the stigma, the length of the longest pollen tube, the number of pollen tubes at the base of the style, and presence/ absence of pollen tubes in the ovary and micropyles. Eight pistils were examined per cross.

EFFECT OF GROWTH REGULATORS ON FRUIT SET AND EMBRYO DEVELOPMENT IN INTERGENERIC CROSSES. The objective of this study was to determine if plant growth regulators would delay fruit abscission and promote seed development in Easter cactus following intergeneric crosses. BA, $\mathrm{GA}_{3}$, and NAAm were mixed individually in hot $\left(\approx 140{ }^{\circ} \mathrm{C}\right)$ lanolin at concentrations of 0.1 and $1.0 \%(\mathrm{w} / \mathrm{v})$. The mixtures were stored at $2{ }^{\circ} \mathrm{C}$ and warmed to $20{ }^{\circ} \mathrm{C}$ before application (Emsweller, 1954). Flowers of 'Crimson Giant' were pollinated with pollen from $S$. truncata 'Rocket'. A small, vshaped nick $(\approx 0.5 \mathrm{~cm})$ was made on the ovary wall immediately after pollination and $\approx 0.2 \mathrm{~mL}$ of a growth regulator suspension or lanolin alone (control) was applied to the nick. The experiment consisted of seven treatments (three growth regulators $\times$ two concentrations plus a lanolin control) with 23 to 26 flowers per treatment. Multiple flowers were pollinated on each plant but only one treatment was applied per plant to avoid confounding effects.

Fruit were harvested at 160 DAP and ovules were dissected under a stereomicroscope $(\times 32)$. Percent fruit set was calculated for each treatment. Number of ovules containing embryos was determined for each fruit and, if present, the length of the embryo was measured. 
ISOZYME ANALYSIS OF PUTATIVE INTERGENERIC HYBRIDS. ISOZYME patterns of four putative intergeneric hybrids and their parents [ $S$. xbuckleyi S9219-2 (female) x H. xgraeseri R9312-5, R9346-6, and R914-1] were analyzed to verify the parentage of the progeny. Phylloclade tissue $(\approx 8 \mathrm{mg})$ was macerated in a microcentrifuge tube containing $120 \mu \mathrm{L}$ cold extraction buffer [50 mM Tris-HCl buffer (pH 7.5), 14 mм 2-mercaptoethanol,5\% (w/v) polyvinylpyrrolidone (PVP-40), and 5\% (w/v) sucrose (Wendel and Weeden, 1989)]. Crude homogenates were centrifuged at $10,060 g_{n}$ for 10 $\min$ at $4{ }^{\circ} \mathrm{C}$. About $60 \mu \mathrm{L}$ of the supernatant was mixed with $10 \mu \mathrm{L}$ cold sample loading buffer composed of 50\% (v/v) glycerol and $0.1 \%$ (w/v) bromophenol blue. Native proteins were separated on polyacrylamide gels using a Mini-Protean II cell (Bio-Rad Laboratories, Hercules, Calif.). Gels (5\% to $10 \%$ single percentage or $7.5 \%$ with a $4 \%$ stacking gel) were prepared using $0.375 \mathrm{M}$ Tris$\mathrm{HCl}(\mathrm{pH} 8.8)$ as the buffer (Hames, 1981). The electrode buffer was 0.025 м Tris and 0.192 м glycine (pH 8.3). Sample loading volumes ranged from 5 to $10 \mu \mathrm{L}$. Electrophoresis was conducted at $4{ }^{\circ} \mathrm{C}$ under constant voltage $(200 \mathrm{~V})$. Gels were assayed for seven enzymes: aspartate aminotransferase (AAT, E.C. 2.6.1.1), glucose-6-phosphate isomerase (GPI, E.C. 5.3.1.9), leucine aminopeptidase (LAP, E.C. 3.4.11.1), malate dehydrogenase (MDH, E.C. 1.1.1.37), phosphoglucomutase (PGM, E.C. 5.4.2.2), shikimate dehydrogenase (SKD, E.C. 1.1.1.25), and triosephosphate isomerase (TPI, E.C. 5.3.1.1). The recipes of Wendel and Weeden (1989) were used for staining gels.

MORPHOLOGY, COLOR, AND FLOWERING PERIODS OF THE INTERGENERIC HYBRIDS AND THEIR PARENTS. Morphological data were collected from pot-grown plants of one intergeneric hybrid, the maternal parent (S. ×buckleyi S9219-2), and one of the pollen parents (H. xgraeseri R9346-6). Flower color was characterized qualitatively with the Royal Horticultural Society (RHS) Colour Chart (Royal Horticultural Society, 1966). Petals, stigmas, styles, and ovaries were compared with the RHS ColourChart to determine the color chip(s) closest to the predominant color. Data were collected between Jan. and Dec. 2000. Anthers were dissected under a stereomicroscope $(\times 32)$ to determine if pollen grains were present. The period of flowering under natural daylengths was also recorded for each of the three clones.

DaTA ANALYSIS. Percentage data were analyzed by chi-square tests

Table 2. Influence of Easter cactus (Hatiora) clone on flower morphology and yields of fruit and seeds in intraspecific and intergeneric crosses.

\begin{tabular}{|c|c|c|c|c|c|c|}
\hline \multirow[b]{2}{*}{$\begin{array}{l}\text { Hatiora } \\
\text { clone }\end{array}$} & \multicolumn{2}{|c|}{ Length (mm) } & \multirow[b]{2}{*}{$\begin{array}{l}\text { Pollen } \\
\text { sourcey }\end{array}$} & \multirow[b]{2}{*}{$\begin{array}{c}\text { No. flowers } \\
\text { pollinated }\end{array}$} & \multirow[b]{2}{*}{$\begin{array}{c}\text { Fruit set } \\
(\%)\end{array}$} & \multirow{2}{*}{$\begin{array}{c}\text { Viable seeds/ } \\
\text { pollinated } \\
\text { flower }^{\mathrm{x}}\end{array}$} \\
\hline & $\begin{array}{c}\text { Stigma } \\
\text { lobes }\end{array}$ & Style & & & & \\
\hline AG942 & $2.9 \mathrm{~d}^{\mathrm{w}}$ & $10.8 \mathrm{~d}$ & $\mathrm{EC}$ & 25 & 52 & 5.9 \\
\hline \multirow[t]{2}{*}{ Bonn 06524} & $4.5 \mathrm{~b}$ & $16.6 \mathrm{~b}$ & $\mathrm{EC}$ & 17 & 100 & 185.4 \\
\hline & & & $\mathrm{HC}$ & 30 & 7 & 0 \\
\hline Crimson Giant & $4.5 \mathrm{~b}$ & $17.3 \mathrm{a}$ & $\mathrm{EC}$ & 27 & 100 & 145.8 \\
\hline \multirow[t]{2}{*}{ R962-45 } & $5.0 \mathrm{a}$ & $14.5 \mathrm{c}$ & $\mathrm{EC}$ & 20 & 85 & 65.4 \\
\hline & & & $\mathrm{HC}$ & 99 & 27 & 0 \\
\hline \multirow[t]{2}{*}{ R963-7 } & $4.0 \mathrm{c}$ & $14.5 \mathrm{c}$ & $\mathrm{EC}$ & 17 & 100 & 152.7 \\
\hline & & & $\mathrm{HC}$ & 115 & 53 & 0 \\
\hline Significance & $* * *$ & $* * *$ & & & & \\
\hline
\end{tabular}

${ }^{2}$ Distance from the base of the stigma lobes to the entrance of the ovary cavity.

yEC $=$ Easter cactus $(H . \times$ graeseri $) ; \mathrm{HC}=$ holiday cactus $(S$. truncata or $S . \times$ buckleyi) .

xMean of six to eight fruit for crosses with other Hatiora cultivars.

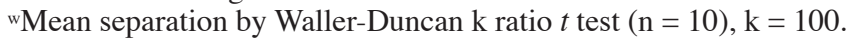

${ }^{* * *}$ Significant at $P<0.001$ by $\mathrm{F}$ test.

Table 3. Effect of holiday cactus (Schlumbergera) clone on flower morphology and yields of fruit and seeds in intraspecific and intergeneric crosses.

\begin{tabular}{|c|c|c|c|c|c|c|}
\hline \multirow[b]{2}{*}{$\begin{array}{l}\text { Schlumbergera } \\
\text { clone }\end{array}$} & \multicolumn{2}{|c|}{ Length (mm) } & \multirow[b]{2}{*}{$\begin{array}{l}\text { Pollen } \\
\text { sourcey }\end{array}$} & \multirow[b]{2}{*}{$\begin{array}{l}\text { No. flowers } \\
\text { pollinated }\end{array}$} & \multirow[b]{2}{*}{$\begin{array}{c}\text { Fruit set } \\
(\%)\end{array}$} & \multirow{2}{*}{$\begin{array}{c}\text { Viable seeds/ } \\
\text { pollinated } \\
\text { flower }^{x}\end{array}$} \\
\hline & $\begin{array}{c}\text { Stigma } \\
\text { lobes }\end{array}$ & Style $^{z}$ & & & & \\
\hline Abendroth 6 & $3.9 \mathrm{bc}^{\mathrm{w}}$ & $57.9 \mathrm{c}$ & $\mathrm{HC}$ & 30 & 100 & 199.7 \\
\hline \multirow[t]{2}{*}{ Dark Marie } & $4.0 \mathrm{~b}$ & $66.3 \mathrm{a}$ & $\mathrm{HC}$ & 20 & 95 & 250.2 \\
\hline & & & $\mathrm{EC}$ & 25 & 0 & -- \\
\hline Rocket & $3.7 \mathrm{c}$ & $63.2 \mathrm{~b}$ & $\mathrm{HC}$ & 50 & 100 & 229.5 \\
\hline \multirow[t]{2}{*}{ S90-38 } & $4.9 \mathrm{a}$ & $54.1 \mathrm{~d}$ & $\mathrm{HC}$ & 8 & 75 & 147.3 \\
\hline & & & $\mathrm{EC}$ & 100 & 0 & --- \\
\hline \multirow[t]{2}{*}{ S9219-2 } & $3.0 \mathrm{~d}$ & $31.0 \mathrm{e}$ & $\mathrm{HC}$ & 49 & 94 & 115.3 \\
\hline & & & $\mathrm{EC}$ & 51 & 98 & 0.1 \\
\hline Significance & $* * *$ & $* * *$ & & & & \\
\hline
\end{tabular}

${ }^{2}$ Distance from the base of the stigma lobes to the entrance of the ovary cavity.

yEC $=$ Easter cactus $(H . \times$ graeseri $) ; \mathrm{HC}=$ holiday cactus $(S$. truncata or $S$. $\times$ buckleyi)

xMean of 50 fruit for S9219-2 x Hatiora; mean of six fruit for all other crosses.

"Mean separation by Waller-Duncan $\mathrm{k}$ ratio $t$ test $(\mathrm{n}=10), \mathrm{k}=100$.

*** Significant at $P<0.001$ by $\mathrm{F}$ test. 
and other dependent variables were analyzed by analysis of variance (ANOVA) using SAS Institute's (1987) ANOVA procedure.

\section{Results}

Fruit AND SEED SET FOLLOWING INTRA- AND INTERGENERIC CROSSES. All five Easter cactus clones set fruit when crossed with $H$. $\times$ graeseri pollen, and four of the five clones set fruit following intergeneric crosses. However, fruit obtained from intergeneric crosses did not contain viable seeds while those produced from intrageneric crosses yielded 5.9 to 185.4 viable seeds per pollinated flower (Table 2). Percent fruit set was $\geq 75 \%$ and mature fruit contained numerous viable seeds when the five holiday cactus clones were crossed using $S$. truncata/S. xbuckleyi pollen (Table 3 ). In contrast, all holiday cactus clones except for S9219-2 failed to set fruit following intergeneric crosses. Fruit set was $98 \%$ when S9219-2 was crossed with $H$. $\times$ graeseri, but only six viable seeds were obtained from 50 fruit. Four putative hybrids survived to maturity.

There were significant differences among the five Easter cactus clones in the lengths of stigma lobes and styles (Table 2). Styles of AG942 were only two-thirds the length of the other Easter cactus clones. The five holiday cactus clones also varied significantly in stigma and style length (Table 3). Stigmas and styles of S9219-2 were about half as long as those of the other four clones.
Pollen germination and POllen tube growth fOllowing INTRA- AND INTERGENERIC CROSSES. By $72 \mathrm{~h}$ after pollination, $H . \mathrm{x}$ graeseri pollen had germinated on 'Crimson Giant' stigmas and pollen tubes had traversed to the ovary (Table 4). Pollen tubes had entered the micropyles of most ovules by $72 \mathrm{~h}$ after intrageneric crosses. Schlumbergera pollen did not exhibit any abnormal responses with regard to adhesion and germination on 'Crimson Giant' stigmas or pollen tube growth in the upper style, but significantly fewer pollen tubes were observed at the base of the style $72 \mathrm{~h}$ after pollination (Table 4). After entering the ovary, most Schlumbergera pollen tubes became twisted and lost directionality whereas others burst at their apices. Several Schlumbergera pollen tubes were coiled tightly in close proximity to micropyles, but none of the ovules had been penetrated successfully by Schlumbergera pollen tubes.

Myriads of germinated pollen grains were present on stigmas of 'Rocket' and S9219-2 at $72 \mathrm{~h}$ after intrageneric crosses, and a single pollen tube had entered the micropyle of most ovules (Table 4). Ovules with pollen tubes were readily detected due to deposition of fluorescent callose (a polysaccharide composed mainly of 1,3 $\beta$-glucan) in the micropylar region, and this phenomenon was not observed in ovules without pollen tubes. For intergeneric crosses with 'Rocket', pollen germination on the stigma and pollen tube growth in the upper style appeared normal but pollen tubes had traversed only $75 \%$ of the length of the pistil by $72 \mathrm{~h}$ after pollination (Table 4). For S9219-2, however, similar numbers of

Table 4. Pollen tube growth following intra- and intergeneric crosses between Hatiora and Schlumbergera.

\begin{tabular}{|c|c|c|c|c|}
\hline \multirow{2}{*}{$\begin{array}{l}\text { Cross } \\
(\text { female } x \text { male })^{z}\end{array}$} & \multirow{2}{*}{$\begin{array}{c}\text { Longest } \\
\text { pollen tube } \\
(\%)^{y}\end{array}$} & \multirow{2}{*}{$\begin{array}{c}\text { No. pollen } \\
\text { tubes at } \\
\text { base of style }\end{array}$} & \multicolumn{2}{|c|}{ Extent of pollen tube growth ${ }^{w}$} \\
\hline & & & In ovary & Entering micropyles \\
\hline 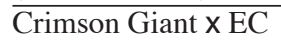 & - & 252.0 & + & + \\
\hline Significance & & $* * *$ & & \\
\hline Rocket $\times$ HC & - & 203.3 & + & + \\
\hline Rocket $x$ EC & $75.8 \pm 3.1$ & 0 & - & - \\
\hline S9219-2 x HC & - & 241.0 & + & + \\
\hline S9219-2 x EC & - & 243.9 & + & + \\
\hline Significance & & NS & & \\
\hline
\end{tabular}

${ }^{\mathrm{z}} \mathrm{EC}=$ Easter cactus $(H . \times$ graeseri $) ; \mathrm{HC}=$ holiday cactus $($ S. truncata or $S . \times$ buckleyi).

$\mathrm{y}$ Expressed as a percentage of the total length of the pistil (stigma lobes + style); $\mathrm{n}=8$.

xMean of eight styles.

wresence $(+)$ or absence $(-)$ of pollen tubes.

NS,***Not significant or significant at $P<0.001$ by $\mathrm{F}$ test, respectively.

Table 5. Effect of plant growth regulators on percent fruit set, seeds per fruit, percent germination, and viable seeds per flower for the intergeneric cross Hatiora gaertneri 'Crimson Giant' (as female) x Schlumbergera truncata 'Rocket'.

\begin{tabular}{|c|c|c|c|c|c|c|}
\hline $\begin{array}{l}\text { Growth } \\
\text { regulator } \\
\text { treatment }{ }^{2} \\
\end{array}$ & $\begin{array}{c}\text { Fruit } \\
\text { set } \\
(\%)^{y}\end{array}$ & $\begin{array}{c}\text { Fruit } \\
\text { examined } \\
\text { (no.) }\end{array}$ & $\begin{array}{c}\text { Fruit } \\
\text { with embryos } \\
\text { (no.) }\end{array}$ & $\begin{array}{c}\text { Embryos } \\
\text { per fruit } \\
(\text { no. })^{x}\end{array}$ & $\begin{array}{c}\text { Embryo } \\
\text { length } \\
(\mathrm{mm})\end{array}$ & $\begin{array}{c}\text { Embryos } \\
\text { per treated } \\
\text { flower (no.) }\end{array}$ \\
\hline$\overline{\text { Control (lanolin) }}$ & 21 & 5 & 1 & 1 & 0.3 & 0.04 \\
\hline $1.0 \% \mathrm{BA}$ & $0^{*}$ & --- & --- & --- & --- & --- \\
\hline $0.1 \% \mathrm{GA}_{3}$ & $85^{*}$ & 21 & 7 & $1-2$ & $0.2-0.5$ & 0.27 \\
\hline $1.0 \% \mathrm{GA}_{3}$ & $75^{*}$ & 19 & 1 & 2 & $0.8-1.0$ & 0.04 \\
\hline
\end{tabular}

$\overline{\mathrm{z}} \mathrm{BA}=$ benzyladenine; $\mathrm{GA}_{3}=$ gibberellic acid; NAAm = naphthaleneacetamide. All growth regulators were applied to the ovary immediately following pollination. 23 to 26 flowers were pollinated per treatment.

y (No. fruit set $\div$ no. flowers pollinated $) \times 100$. Data collected $160 \mathrm{~d}$ after pollination

xData collected $160 \mathrm{~d}$ after pollination.

*Treatment significantly different from control by chi-square test, $P=0.05, \chi^{2}=3.84$ for $1 \mathrm{df}$. 


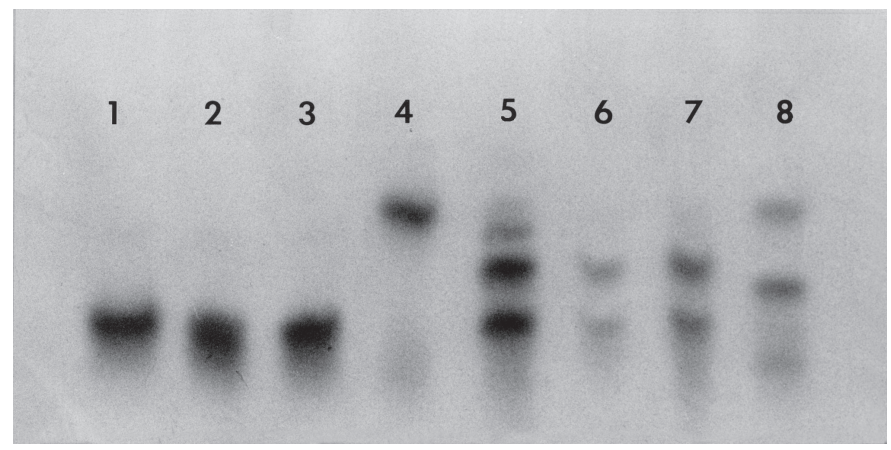

Fig. 1. Glucose-6-phosphate isomerase (GPI) banding patterns for three Hatiora $\times$ graeseri clones (lanes 1 to 3), Schlumbergera $\times$ buckleyi S9219-2 (lane 4), and four hybrids from the cross S9219-2 (as female) $\times$ H. $\times$ graeseri (lanes 5 to 8 ).

Hatiora and Schlumbergera pollen tubes had reached the base of the style by $72 \mathrm{~h}$ after pollination (Table 4). Hatiora pollen tubes had penetrated many ovules of S9219-2 by $72 \mathrm{~h}$ after pollination. Callose was present in the micropylar region of ovules that had been penetrated by a pollen tube.

EFFECT OF GROWTH REgULATORS ON FRUIT SET AND EMBRYO DEVELOPMENT IN INTERGENERIC CROSSES. Fruit set in 'Crimson Giant' was significantly greater when $\mathrm{GA}_{3}$ or NAAm were applied to ovaries compared to lanolin alone (control) or BA (Table 5). Percent fruit set was similar for fruit treated with either $0.1 \% \mathrm{BA}$ or lanolin, but all of the ovaries treated with $1.0 \%$ BA abscised by 160 DAP. Chi-square tests indicated that, for each growth regulator, percent fruit set at 160 DAP was not affected by concentration $(0.1 \%$ or $1.0 \%)$.

A total of 94 fruit was harvested at 160 DAP. Few of the fruit contained embryos and no more than two embryos were found in any one fruit (Table 5). Embryos were observed in some fruit that received lanolin only or $\mathrm{GA}_{3}$ but none of the fruit treated with $\mathrm{BA}$ or NAAm contained embryos. The number of embryos per treated
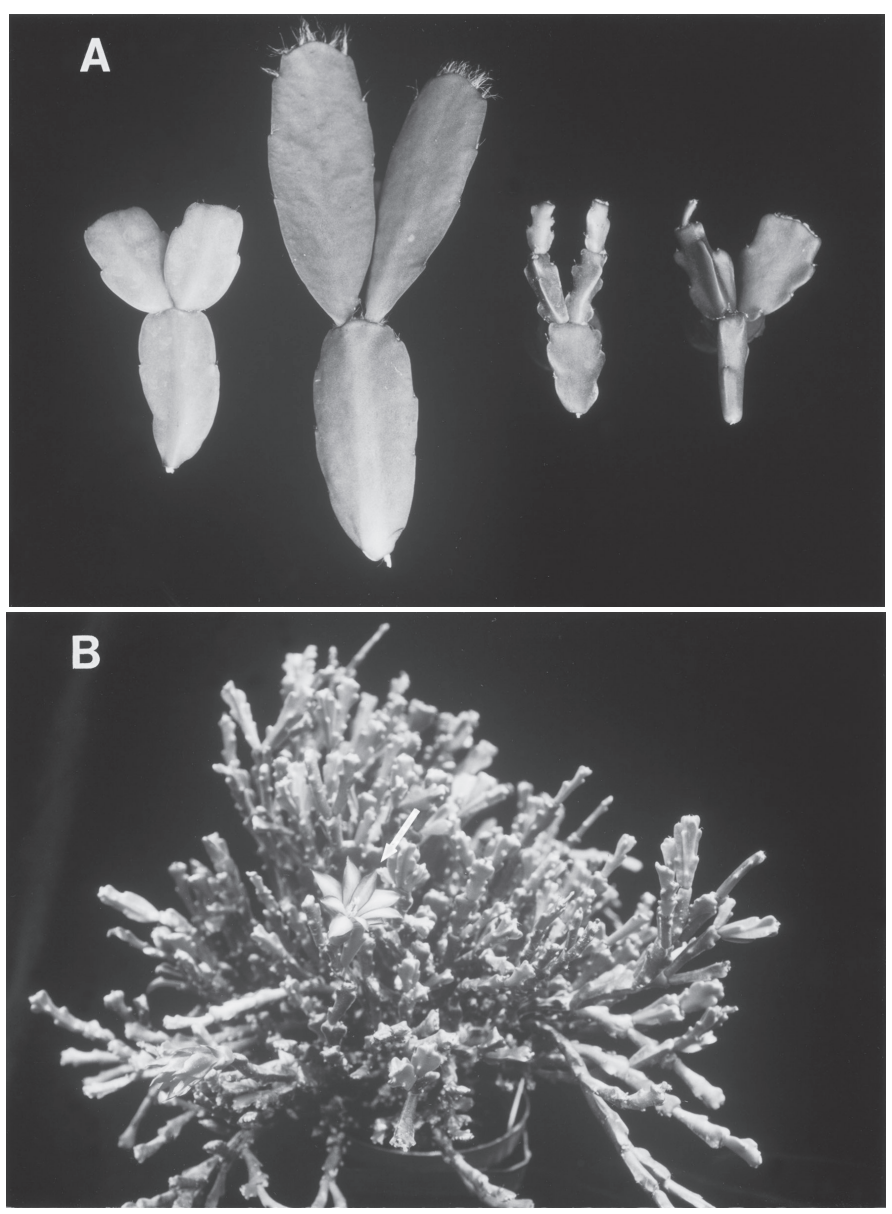

Fig. 2. (A) Phyllocades of Schlumbergera $\times$ buckleyi S9219-2 (far left), Hatiora $\times$ graeseri $\mathrm{R} 9346-6$ (second from left), and two intergeneric hybrids from the cross S9219-2 x H. ×graeseri. (B) Intergeneric hybrid 95-1 in flower (arrow).

Table 6. Morphological and flowering characteristics of a Schlumbergera $\mathrm{x}$ Hatiora intergeneric hybrid and its parents.

\begin{tabular}{|c|c|c|c|}
\hline \multirow[b]{2}{*}{ Character } & \multicolumn{3}{|c|}{ Clone } \\
\hline & $\begin{array}{l}\text { S. } \times \text { buckleyi } \\
\text { S9219-2 }\end{array}$ & $\begin{array}{l}\text { H. ×graeseri } \\
\text { R9346-6 }\end{array}$ & $\begin{array}{c}\text { Intergeneric hybrid } \\
95-1\end{array}$ \\
\hline Filament arrangement & Two series & Two series & One series \\
\hline Filament color (RHS) & White (155D) & Red-purple (67B) & White (155D) \\
\hline Flower size $(\mathrm{mm})$ & $45 \times 40$ & $40 \times 40$ & $45 \times 35$ \\
\hline Flower symmetry & Zygomorphic & Actinomorphic & Actinomorphic \\
\hline Flower tube length (mm) & 15 & 0 (no tube) & 8 \\
\hline Flowering period & Dec. to Apr. & $\begin{array}{l}\text { Apr. and May (main); } \\
\text { July to Sept. (2nd) }\end{array}$ & July to Aug. \\
\hline Ovary color (RHS) & Green (137A) & Brown (183A) & Green (152A) \\
\hline Ovary shape & Oblong with slight ribs & Oblong with prominent ribs & Oblong with irregular ribs \\
\hline Petal color (RHS) & Red-purple (74AB) & $\operatorname{Red}(53 \mathrm{BC})$ & Red (53B) and light orange (26B) \\
\hline Phylloclade margins & $\begin{array}{r}\text { Crenulate at base; } \\
\text { serrulate at apex }\end{array}$ & Crenulate & Crenate \\
\hline Phylloclade shape & Flattened; oblong & Flattened; oblong & Flattened to 3-4 angled; oblanceolate to flabellate \\
\hline Phylloclade size (mm) & $35 \times 20$ & $60 \times 23$ & $28 \times 10$ \\
\hline Stigma color (RHS) & Red-purple (74A) & White (155D) & White (155D) \\
\hline Style length (mm) & 32 & 15 & 25 \\
\hline Stigma lobes & Erect and connivent & Deflexed & Deflexed \\
\hline Stigma lobe length $(\mathrm{mm})$ & 4 & 5 & 5 \\
\hline Style color (RHS) & $\begin{array}{l}\text { Red-purple (74A) } \\
\text { throughout }\end{array}$ & $\begin{array}{l}\text { Red-purple (74A) in upper half; } \\
\text { white (155D) in lower half }\end{array}$ & Red-purple (74A) throughout \\
\hline
\end{tabular}


flower ranged from 0 to 0.27 , with $0.1 \% \mathrm{GA}_{3}$ yielding the most embryos. All embryos were immature and no attempts were made to culture the embryos in vitro.

IsOZYME ANALYSIS. Isozymes for LAP, MDH, SKD, and TPI were resolved but the resulting banding patterns did not provide unequivocal proof of intergeneric hybridization. Confirmation of hybridity, however, was obtained with AAT, GPI, and PGM. The GPI banding patterns for the parents and progeny are shown in Fig. 1. The three possible pollen parents (H. × graeseri) displayed one or two rapidly migrating bands whereas the female parent (S9219-2) produced one slow band. The four progeny yielded one or two bands that were identical to parental clones plus some unique bands with intermediate mobility which were not present in either parent (Fig. 1).

MORPHOLOGY, COLOR, AND FLOWERING PERIODS OF THE INTERGENERIC HYBRIDS AND THEIR PARENTS. The parental clones produced oblong, flattened (two-ribbed) phylloclades but the intergeneric hybrids yielded phylloclades that were oblanceolate to flabellate with two, three, or four ribs (Fig. 2A). Only one of the four intergeneric hybrids produced flowers. The flowering hybrid (= 95-1) resembled the female parent (S. ×buckleyi S9219-2) in phylloclade size and filament color but was similar to pollen parent $(H . \times$ graeseri R9346-6) in flower symmetry, petal color, stigma lobe orientation, and stigma color (Table 6). 95-1 was intermediate with respect to flower tube length, style length, and style color but differed from both parents in phylloclade shape, flower size, filament arrangement, ovary shape and color, and flowering period (Table 6; Fig. 2B). All of the anthers collected from flowers of 95-1 were devoid of pollen grains.

\section{Discussion}

Four progeny were obtained when S. xbuckleyi S9219-2 was used as the female parent in crosses with $H$. xgraeseri. Isozyme patterns (Fig. 1) and morphological features (Table 6 and Fig. 2) demonstrated that all four progeny were intergeneric hybrids of Schlumbergera and Hatiora. This is the first report of intergeneric hybridization between Hatiora and Schlumbergera and between two genera in the tribe Rhipsalideae (Barthlott, 1987).

Following intergeneric crosses, four of the five Easter cactus clones set fruit while only one of the five holiday cactus clones yielded fruit (Tables 2 and 3). Most pollen tubes were inhibited in the style when $S$. truncata 'Rocket' was crossed as female with Hatiora (Table 4). In the reciprocal cross (H. gaertneri 'Crimson Giant' $\times$ Schlumbergera), pollen tubes were able to reach the ovary but failed to enter the micropyle (Table 4). Presence of Schlumbergera pollen tubes in 'Crimson Giant' ovaries was sufficient to induce 17\% fruit set although fertilization rarely occurred (Table 2). Reciprocal differences in the amount of fruit set following intergeneric crosses between Hatiora and Schlumbergera thus appears to be dependent on the site of pollen tube arrest in the pistil.

Wide-cross hybrids may be difficult to obtain in species with multilocular ovaries when seed set is inadequate to prevent fruit abscission (Hadley and Openshaw, 1980). One technique that has been used successfully to increase fruit and seed set in wide crosses is application of growth regulators to the anther column, pistil or calyx (Al-Yasiri and Coyne, 1964; Larter and Chaubey, 1965; Payan and Martin, 1975). Application of $\mathrm{GA}_{3}$ or NAAm to 'Crimson Giant' ovaries reduced fruit abscission but no mature embryos were recovered (Table 2). $\mathrm{GA}_{3}$ and NAAm also increased fruit set when applied to selfed flowers of 'Crimson Giant' (Boyle et al., 1994). Our results suggest that growth regulators such as
$\mathrm{GA}_{3}$ or NAAm may aid in the recovery of intergeneric hybrids between Hatiora and Schlumbergera by minimizing or preventing fruit abscission. However, barriers other than low fruit set must be overcome to increase the success rate in crossing Easter cactus (as female) with holiday cactus.

Another technique that has been employed to secure hybrids when crossing short-styled and long-styled taxa is to use the shortstyled plant as the female parent (Fehr, 1993). The rationale for this practice is based on the notion that pollen from short-styled flowers may be unable to fertilize ovules in long-styled flowers due to their inability to traverse the full length of the style. Generally, style length ranges from 11 to $25 \mathrm{~mm}$ in Easter cactus and from 50 to $70 \mathrm{~mm}$ in holiday cactus (T.H. Boyle, unpublished data). In our study, greater difficulty was experienced in crossing short-styled Hatiora as the female parent than in the reciprocal cross. However, the short-styled $x$ long-styled technique proved successful in Schlumbergera $\mathrm{x}$ Hatiora crosses. Stylar barriers to crossing Hatiora with Schlumbergera were overcome by using a short-styled Schlumbergera clone as the maternal parent. Styles of S9219-2 are $\geq 20 \mathrm{~mm}$ shorter than other Schlumbergera cultivars (Table 4). These results as well as those from several other studies (Boyle and Stimart, 1987; Chen et al., 1983; Custers and den Nijs, 1986; Gradziel and Robinson, 1989; Harlan and de Wet, 1977; Snape et al., 1979) underscore the importance of utilizing diverse germplasm in wide crosses to maximize the probability of success.

The progenitor species for Easter cactus (H. gaertneri and $H$. rosea) are geographically isolated from the progenitors of holiday cactus (S. truncata and S. russelliana); the former species are native to the states of Paraná, Santa Catarina, and Rio Grande do Sul in southeast Brazil while the latter species are found farther north near Rio de Janeiro (Barthlott and Taylor, 1995). Taxa in different genera would be expected to exhibit strong reproductive isolation, and the pre- and postzygotic barriers encountered in crossing Easter cactus with holiday cactus are probably due to incongruity (Hogenboom, 1975, 1984). Before the mid-1970s, barriers encountered in crossing different angiosperm taxa were attributed frequently to the action of self-incompatibility $(S)$ genes rather than evolutionary divergence [see de Nettancourt (1977)]. Although self-incompatibility (SI) occurs in Easter cactus (Boyle et al., 1994) and holiday cactus (Boyle, 1996), it is unlikely that SI is a barrier to hybridization between these two crops. Evidence to support this hypothesis is based on differences in pollen tube growth in selfed or intergenerically crossed pistils. For example, when 'Crimson Giant' flowers were selfed, most pollen tubes were arrested in the middle to lower third of the style and relatively few ( $\leq 6)$ pollen tubes reached the base of the style by $72 \mathrm{~h}$ after pollination (Boyle et al., 1994). However, numerous $(\approx 150)$ pollen tubes had traversed the style by $72 \mathrm{~h}$ after applying Schlumbergera pollen to 'Crimson Giant' pistils (Table 4). Similar results were obtained with S. xbuckleyi S9219-2, i.e., selfed flowers failed to set fruit due to stylar arrest of pollen tubes (T.H. Boyle, unpublished data) while flowers pollinated with Hatiora pollen contained as many pollen tubes at the base of the style as those treated with compatible Schlumbergera pollen (Table 4).

Harlan and de Wet (1971) classified taxa into one of three gene pools based on their crossability with cultivars of a particular crop and the growth and fertility of hybrids. Taxa are assigned to the primary gene pool (GP-1) if barriers to hybridization are few or nonexistent and hybrids are fertile with approximately normal gene segregation. For taxa in the secondary gene pool (GP-2), barriers to hybridization are more prevalent and/or hybrids are less fertile than those obtained with GP-1. The tertiary gene pool 
(GP-3) includes taxa that are difficult to cross with cultivars using conventional breeding techniques and the resulting hybrids are completely sterile or lethal. Transfer of genes from GP-3 taxa to cultivated plants commonly requires special techniques to obtain fertile hybrids, e.g., embryo culture, induced polyploidy, or use of bridging species. The post-pollination reproductive barriers associated with crossing Hatiora and Schlumbergera and the sparse flowering and apparent sterility of the intergeneric hybrids indicates that Easter cactus should be assigned to the GP-3 for holiday cactus, and vice versa.

The current study has shown that it is possible to circumvent the post-pollination barriers to intergeneric hybridization between Schlumbergera and Hatiora. Thus far, only one intergeneric hybrid (95-1) has flowered and it has proven to be male sterile. Use of a genetically diverse array of Hatiora and Schlumbergera clones for intergeneric crosses might yield hybrids with more prolific flowering and greater fertility.

\section{Literature Cited}

Al-Yasiri, S. and D.P. Coyne. 1964. Effect of growth regulators in delaying pod abscission and embryo abortion in the interspecific cross Phaseolus vulgaris $\times$ P. acutifolius. Crop Sci. 4:433-435.

Anderson, E.F. 2001. The cactus family. Timber Press, Portland, Ore.

Barthlott, W. 1987. New names in Rhipsalidinae (Cactaceae). Bradleya 5:97-100.

Barthlott, W. and W. Rauh. 1977. Die Wildarten und Hybriden der Weihnachtskakteen (Gattung Schlumbergera). Kakteen und andere Sukkulenten 28:273-278.

Barthlott, W. and N.P. Taylor. 1995. Notes towards a monograph of Rhipsalideae (Cactaceae). Bradleya 13:43-79.

Boyle, T.H. 1994. A simple method for extracting and cleaning seeds of Rhipsalidopsis and Schlumbergera (Cactaceae). HortTechnology 4:264-265.

Boyle, T.H. 1996. Characteristics of self-incompatibility in Schlumbergera truncata and $S$. ×buckleyi (Cactaceae). Sexual Plant Reprod. 9:49-53.

Boyle, T.H. 1997. Holiday and Easter cactus, p. 82-88. In: M.L. Gaston, S.A. Carver, C.A. Irwin, and R.A. Larson (eds.). Tips on growing specialty potted crops. Ohio Florists' Assn., Columbus.

Boyle, T.H. 2001. Environmental control of moisture content and viability in Schlumbergera truncata (Cactaceae) pollen. J. Amer. Soc. Hort. Sci. 126:625-630.

Boyle, T.H. and D.P. Stimart. 1987. Influence of Zinnia angustifolia HBK genotype on embryonic and vegetative development of $Z$. angustifolia $\times$ Z. elegans Jacq. interspecific hybrids. Theoretical Appl. Genet. 73:716-723.

Boyle, T.H., F.D. Menalled, and M.C. O’Leary. 1994. Occurrence and physiological breakdown of self-incompatibility in Easter cactus. J. Amer. Soc. Hort. Sci. 119:1060-1067.

Chen, N.C., L.R. Baker, and S. Honma. 1983. Interspecific crossability among four species of Vigna food legumes. Euphytica 32:925-937.

Custers, J.B.M. and A.P.M. den Nijs. 1986. Effects of aminoethoxyvinylglycine (AVG), environment, and genotype in overcoming hybridization barriers between Cucumis species. Euphytica 35:639-647.

de Nettancourt, D. 1977. Incompatibility in angiosperms. Springer Verlag, Berlin.

Emsweller, S.L. 1954. Plant regulators and plant breeding, p. 161-169. In: H.B. Tukey (ed.). Plant regulators in agriculture. Wiley, New York.

Fehr, W.R. 1993. Principles of cultivar development. vol. 1. Theory and technique. Univ. Bookstore, Iowa State Univ., Ames.
Gradziel, T.M. and R.W. Robinson. 1989. Solanum lycopersicoides gene introgression to tomato, Lycopersicon esculentum, through the systematic avoidance and suppression of breeding barriers. Sexual Plant Reprod. 2:43-52.

Hadley, H.H. and S.J. Openshaw, 1980. Interspecific and intergeneric hybridization, p. 133-159. In: W.R. Fehr and H.H. Hadley (eds.). Hybridization in crop plants. Amer. Soc. Agron. and Crop Sci. Soc. Amer., Madison, Wisconsin.

Hames, B.D. 1981. An introduction to polyacrylamide gel electrophoresis, p. 1-86. In: B.D. Hames and D. Rickwood (eds.). Electrophoresis of proteins: A practical approach. IRL Press Ltd., Oxford, England.

Harlan, J.R. and J.M.J. de Wet. 1971. Toward a rational classification of cultivated plants. Taxon 20:509-517.

Harlan, J.R. and J.M.J. de Wet. 1977. Pathways of genetic transfer from Tripsacum to Zea mays. Proc. Natl. Acad. Sci. USA 74:3494-3497.

Hawkes, M.W. 1982. Hybridization in the Cactaceae, part II. Cactus Succulent J. (U.S.) 54:243-246.

Hawkes, M.W. 1983. Hybridization in the Cactaceae, conclusion. Cactus Succulent J. (U.S.) 55:31-36.

Hogenboom, N.G. 1975. Incompatibility and incongruity: two different mechanisms for the non-functioning of intimate partner relationships. Proc. Royal Soc. London, Ser. B 188:361-365.

Hogenboom, N.G. 1984. Incongruity: non-functioning of intercellular and intracellular partner relationships through non-matching information, $\mathrm{p}$. 641-654. In: H.F. Linskens and J. Heslop-Harrison (eds.). Encyclopedia of plant physiology (new series). vol. 17. Springer Verlag, Berlin.

Karle, R. and T.H. Boyle. 1999. Relationships between floral morphology, breeding behavior, and flower longevity in Easter cactus. J. Amer. Soc. Hort. Sci. 124:296-300.

Ladizinsky, G. 1992. Crossability relations, p. 15-31. In: G. Kalloo and J.B. Chowdhury (eds.). Distant hybridization of crop plants. SpringerVerlag, Berlin.

Langton,F.A. 1987. Breeding for improved ornamental plants, p. 159-180. In:A.J.Abbott and R.K.Atkin (eds.). Improving vegetatively propagated crops. Academic Press, London.

Larter, E. and C. Chaubey. 1965. Use of exogenous growth substances in promoting pollen tube growth and fertilization in barley-rye crosses. Can. J. Genet. Cytol. 7:511-518.

Martin, F.W. 1959. Staining and observing pollen tubes in the style by means of fluorescence. Stain Technol. 34:125-128.

McMillan, A.J.S. and J.F. Horobin. 1995. Christmas cacti: The genus Schlumbergera and its hybrids. David Hunt, Dorset, U.K.

Moran, R. 1953. Taxonomic studies in the Cactaceae. II. Notes on Schlumbergera, Rhipsalidopsis, and allied genera. Gentes Herb. 8:328-345.

Parks, C.A. 2003. Chromosome numbers and pollen cytology in Hatiora and Schlumbergera (Cactaceae). MS thesis, Univ. Mass., Amherst.

Payan, F.R. and F.W. Martin. 1975. Barriers to hybridization of Passiflora species. Euphytica 24:709-716.

Rowley, G.D. 1994. Spontaneous bigeneric hybrids in Cactaceae. Bradleya 12:2-7.

Royal Horticultural Society. 1966. Royal Horticultural Society colour chart. Royal Hort. Soc., London.

SAS Institute Inc. 1987. SAS/STAT guide for personal computers. version 6 ed. SAS Inst. Inc., Cary, N.C.

Schumann, K. 1902. Phyllocactus gaertneri K. Sch. Blühende Kakteen 1:21. [English translation: Kimnach, M. 1949. Cactus Succulent J. (U.S.) 21:176-177.]

Snape, J.W., V. Chapman, J. Moss, C.E. Blanchard, and T.E. Miller. 1979. The crossabilities of wheat varieties with Hordeum bulbosum. Heredity 42:291-298.

Wendel, J.F. and N.F. Weeden. 1989. Visualization and interpretation of plant isozymes, p. 5-45. In: D.E. Soltis and P.S. Soltis (eds.). Isozymes in plant biology. Dioscorides, Portland, Ore. 